\title{
Evaluation of Antimicrobial Activity of Some Enzymes of Trichoderma harzianum Immobilized on Polyester Cloth Films on The Disease Incidence of Postharvest Black Mold Disease of Tomatoes
}

\author{
Anwer S.M. El-Badry and Samah Abd El-Kader El-Debaiky \\ Botany Department, Faculty of Science, Tanta University, Tanta, Egypt.
}

$\mathbf{T}_{1}^{\mathrm{H}}$ HE CRUDE extract activity was tested in the present study for some enzymes of Trichoderma harzianum, immobilized on polyester cloth films against the postharvest black mold disease of tomato fruit caused by Alternaria alternata. Firstly, the antifungal activity of $T$. harzianum against A. alternata was examined by the dual culture method using PDA plates, as it clearly inhibited the linear growth of A. alternata where the inhibition percentage was $66.5 \%$. The hyphal interactions between both fungi were explored microscopically where hyphae of T. harzianum penetrated inside the hyphae of $A$. alternata then lysed them. The lysis of pathogenic cells was referred to the presence of cellulase, chitinase and glucose oxidase enzymes of $T$. harzianum. These enzymes were assayed quantitatively; then immobilized separately on sterile polyester films where their activity and stability were estimated in both crude cell free filtrates and saturated films. The immobilization of the tested enzymes on the polyester films showed promising findings in raising the enzyme persistence. In the meantime, these enzymatic polyester films were tested as tomato fruit coverage against the postharvest black mold disease at room temperature for 15 days. The cellulase films showed promising results, where they completely lowered the disease incidence to $0 \%$ after 4 and 7 days while it recorded 33.3 and $100 \%$ after 10 and 15 days, respectively.

Keywords: Polyester film, Trichoderma harzianum, Alternaria alternata, Tomatoes, Black mold, Cellulase, Chitinase and Glucose oxidase.

\section{Introduction}

Tomato (Lycospersicon esculentum Mill) is considered one of the most important vegetable crops which is highly distributed all over the world. Egypt is the fifth largest producer of tomatoes in the world where its production of tomatoes exceeds 9 million tons annually (Moussa et al., 2013). These fleshy fruits are rich of several nutritive materials such as carotenoids (e.g. lycopene), phenolics, vitamin $\mathrm{C}$, carbohydrates, proteins, fats and potassium (Causse et al., 2003 and Talvas et al., 2010). Ripe tomato fruits contain approximately $94 \%$ of water, $4.3 \%$ carbohydrates, $1 \%$ protein, $0.1 \%$ fat, $0.6 \%$ fiber and vitamins (Asan \& Ekmekçi, 2002 and Samuel \& Orji, 2015). This indicated that they are suitable to mechanical injury at postharvest handling and practices of storage, transportation and marketing which all affecting the quality of tomato fruit (Sajad \& Jamaluddin Abid, 2017). Moreover, these physical damages coupled with the large water content of tomatoes make them more susceptible to spoilage by fungi (Asan \& Ekmekçi, 2002 and Samuel \& Orji, 2015). Several fungal species are responsible of tomato fruit rots such as Geotrichum candidum, Rhizopus stolonifer, black mold rot caused by Alternaria sp., Fusarium rot by Fusarium sp. (Sajad \& Jamaluddin Abid, 2017). The black mold (Alternaria rot) is caused by the dematiaceous fungus, A. alternata and causing huge postharvest losses in tomato fruit at marketing period (Troncoso-Rojas \& TiznadoHernández, 2014).

Chemical control using fungicides is effective in reduction of many postharvest diseases in various fruit and vegetables (Spotts \& Cervantes, 1986). But, the use of these synthetic chemicals becomes restricted, due to their dangerous effects where lots of them are carcinogenic and highly toxic to human. Also, they have long degradation periods and causing environmental pollution 
(Lingk, 1991). Because of the problems caused by chemical fungicides, many alternative controlling methods of postharvest diseases are developed. In the last decades, many researchers interested in production of antimicrobial films which are used for packaging of food products and saving them from microbial contamination (Cha \& Chinnan, 2004).

Microbial degradation of insoluble macromolecules lignin, cellulose and chitin depends on the production of extracellular enzymes. Cellulases are produced by several microorganisms such as bacteria, yeast and fungi. However, the most extensively studied cellulases are those produced by efficient lignocellulose degrading fungi, particularly Trichoderma (Henrissat et al., 1985). Also, chitinases can hydrolyze the cell walls of many fungi. The microorganisms that can produce these enzymes are able to destroy the cell wall of many pathogenic fungi for nutrition purpose. Some antagonistic fungi such as Trichoderma can attack several plant pathogenic fungi by mycoparasitism as a result of chitinase production (Budi et al., 2000 and Papavizas, 1985).

Glucose oxidase appears to be an important source of $\mathrm{H}_{2} \mathrm{O}_{2}$ in ligninolytic cultures. Glucose supports the highest level of $\mathrm{H}_{2} \mathrm{O}_{2}$ production in cell extracts. Both glucose oxidase and ligninolytic activities were shown to be secondary metabolic events, and both are important in a combination for lignin degradation as a mean of attack by antagonistic fungi. The ability of fungal glucose oxidase to utilize monosaccharides as a substrate may allow the organism to utilize sugars derived not only from cellulose but also from hemicelluloses found in woody material, its natural habitat, to produce $\mathrm{H}_{2} \mathrm{O}_{2}$, which is known to be important to the ligninolytic system and act as an efficient strategy for antagonistic microbial interactions (Kelley \& Reddy, 1986).

The present study was performed due to the great importance of tomato fruits for human consumption in Egypt, and the need for safe preservative methods for them. Accordingly, the present study aimed firstly to produce an antimicrobial film from the polyester cloth amended with some enzymes (cellulase, chitinase and glucose oxidase) of the common antagonist $T$. harzianum. Secondly, to test the activity of these antimicrobial polyester films to protect the tomato fruit against Alternaria black rot postharvest disease.

\section{Materials and Methods}

\section{Tested fungi}

Culture of T. harzianum was purchased from the mycological center, Assiut University, Egypt. While the postharvest pathogenic fungus, $A$. alternata was isolated from spoiled tomatoes. All the cultures were sub-cultured and maintained on potato dextrose agar medium (PDA) at $4^{\circ} \mathrm{C}$ for further work.

\section{Used media}

\section{Potato dextrose agar medium (PDA)}

This medium was prepared using the method found in Moubasher (1993) using the following components $\left(\mathrm{g} \mathrm{L}^{-1}\right)$, potato tubers, 200; D-Glucose, 20. Potatoes were cut after peeling to small cubes and boiled in $1 \mathrm{~L}$ distilled water for $1 \mathrm{~h}$. The filtrate was collected after filtration of potatoes through a cloth piece and thereafter glucose was added. The mixture volume was adjusted to one liter with distilled water. Chloramphenicol antibiotic $(0.05 \%)$ was added to prevent bacterial contamination and agar was added for solidification (2\%). Then, the medium was sterilized in autoclave and stored for further work.

\section{Czapek's dox agar medium (CZA)}

Czapek's dox agar medium (CZA) was used in the enzymes tests for the growth of T. harzianum. The medium has the following composition ( $\mathrm{g}$ $\left.\mathrm{L}^{-1}\right)$; sucrose, 30; sodium Nitrate $\left(\mathrm{NaNO}_{3}\right), 2$; potassium dihydrogen orthophosphate $\left(\mathrm{KH}_{2}^{3} \mathrm{PO}_{4}\right)$, 1; magnesium sulphate $\left(\mathrm{MgSO}_{4}\right), 0.5$; potassium chloride $(\mathrm{KCl}), 0.5$; ferrous sulphate $\left(\mathrm{FeSO}_{4}\right), 0.01$ and agar, 20 (Moubasher, 1993).

Antifungal activity of T. harzianum against $A$. alternata in vitro

The activity of $T$. harzianum in inhibiting the postharvest pathogen, A. alternata was studied using a modified dual culture method adopted by Jamdar et al. (2013). PDA plate was inoculated with $8 \mathrm{~mm}$ disc of $A$. alternata, $10 \mathrm{~mm}$ from the edge of the plate. Then, $8 \mathrm{~mm}$ disc of T. harzianum was cut by sterile cork borer, and then placed in the same plate $60 \mathrm{~mm}$ far from $A$. alternata disc. Three replicates were performed. The inoculated plates were incubated in dark at $27 \pm 2^{\circ} \mathrm{C}$ for 4 days in a static incubator. Control plates were inoculated with $A$. alternata only. After the incubation period, 
the mean diameter of the pathogen growth in dual culture plates was calculated and compared to the control plates. The percentage growth inhibition (\%) was calculated (Vincent, 1947 and Jayasinghe \& Wijesundera, 1995):

$$
\mathrm{I}=(\mathrm{C}-\mathrm{T}) / \mathrm{C} \times 100
$$

where: $\mathrm{I}=$ inhibition percentage, $\mathrm{C}=$ control growth diameter and $\mathrm{T}=$ treatment growth diameter.

The antagonistic mechanisms and hyphal interactions between $T$. harzianum against $A$. alternata were investigated microscopically and photographed.

Quantitative colorimetric assay of offensive enzymes of T. harzianum culture

Preparation of T. harzianum pure liquid

Pure liquid cultures of $T$. harzianum was prepared in flasks containing sterilized liquid Czapek's dox agar medium, modified by changing the carbon source to induce the desired hydrolytic enzyme. Carboxymethyl cellulose was used as a sole carbon source for cellulase production; while, colloidal chitin was used for chitinase and glucose for glucose oxidase. All the flasks were incubated at $27 \pm 2{ }^{\circ} \mathrm{C}$ for 4 days on a shaking incubator $(80 \mathrm{rpm})$ to get the maximum enzyme production during the exponential growth phase.

Extraction of intracellular glucose oxidase enzyme

The cultivated fungal mycelium of $T$. harzianum was filtered and then blended in an ice box to extract intracellular enzymes, and the filtrate was pre-cooled and centrifuged at 6000 rpm for 15 min (Kim et al., 1990). The supernatant was separated from the mycelium pellet through Whatman no.1 filter paper. The clear supernatant was considered as the crude enzyme and stored at $4^{\circ} \mathrm{C}$ for both polyester cloth saturation and for glucose oxidase assay. filtrates

Stability test for all enzymes in the collected

To ensure the stability of the tested enzymes at room temperature in their suspensions, the collected crude enzyme filtrates (both extra and intra cellular) were stored at room temperature $\left(\approx 25^{\circ} \mathrm{C}\right)$ and their activities were assayed after regular intervals $(0,6,12$ and $24 \mathrm{~h}$.).
Cellulase activity: Total extracellular cellulase activity was determined by a modified method adopted by Mandels et al. (1976). An aliquot of $0.5 \mathrm{ml}$ of cell-free culture supernatant was transferred to a clean test tube and $1 \mathrm{ml}$ of sodium citrate buffer ( $\mathrm{pH} 4.8$ ) was added. $0.5 \mathrm{ml}$ of $1 \%(\mathrm{w} / \mathrm{v})$ carboxy methyl cellulose (CMC) was added to each tube as a substrate. Tubes were incubated in a water bath at $50^{\circ} \mathrm{C}$ for $1 \mathrm{~h}$ followed by an addition of $3 \mathrm{ml}$ of di nitro salicylic acid reagent (DNSA). Tubes were then placed in a boiling water bath for $5 \mathrm{~min}$ and then in an icebath, followed by the addition of $15 \mathrm{ml}$ distilled water to each tube. Contents of the tube were mixed, and absorbance was noted at $550 \mathrm{~nm}$ and compared with a standard curve of known glucose concentrations. Enzyme activity was determined in terms of International Unit (Tanaka et al., 1988) which is defined as an amount of enzyme that produces $1 \mu \mathrm{M}$ of glucose per minute under standard assay conditions.

Chitinase activity: Total extracellular chitinase activity was determined by estimating the amount of free reducing groups formed after colloidal chitin hydrolysis (Joshi et al., 1988). The reaction mixture was composed of $0.5 \mathrm{ml}$ of $1 \%$ colloidal chitin suspended in 0.02 $\mathrm{M}$ phosphate buffer $(\mathrm{pH}=7)$ and $0.5 \mathrm{ml}$ of the enzyme solution (cell-free culture filtrate). The mixture was incubated for $30 \mathrm{~min}$ at $40^{\circ} \mathrm{C}, 0.75 \mathrm{ml}$ of DNSA was added, the suspension was heated for $10 \mathrm{~min}$ at $100^{\circ} \mathrm{C}$ and then centrifuged at 5000 rpm for $10 \mathrm{~min}$. The absorbance of supernatant was measured at $530 \mathrm{~nm}$. A standard curve was obtained using $\mathrm{N}$-acetylglucosamine with known concentrations. One unit of chitinase was defined as the amount of enzyme which yields $1 \mu \mathrm{mol}$ of reducing sugar as $\mathrm{N}$-acetylglucosamine equivalent per minute.

Glucose oxidase activity: Glucose oxidase intracellular activity in the crude enzyme extract was determined by spectrophotometer method at $460 \mathrm{~nm}$ using glucose as a substrate (Reese \& Mandels, 1959). $0.5 \mathrm{ml}$ of $1 \%$ glucose dissolved in $0.02 \mathrm{M}$ phosphate buffer $(\mathrm{pH}=7)$ and $0.5 \mathrm{ml}$ of the enzyme solution (cell extract supernatant), then the reaction was allowed for $10 \mathrm{~min}$. The absorbance of the mixture was recorded before and after the reaction to determine the amount of remnant reducing sugar released in the supernatant, compared with a standard curve of $\mathrm{N}$-acetylglucosamine.. 
Preparation of antimicrobial polyester films saturated with crude enzymes extracts of T. harzianum:

Pieces $(15 \times 15 \mathrm{~cm})$ of white unstained clean $100 \%$ polyester cloth were cut, washed twice by distilled water and soaked in distilled water in conical flasks to be sterilized in autoclave at $121^{\circ} \mathrm{C}, 1.5 \mathrm{~atm}$. for $15 \mathrm{~min}$ then cooled at room temperature. The sterile polyester cloth pieces were soaked separately in the previously stored flasks of crude enzymes extracts (extracellular cellulase, chitinase cell-free culture filtrates and the supernatant of intracellular glucose oxidase) overnight at $4^{\circ} \mathrm{C}$. Then representative enzyme-saturated polyester films were assayed for different enzyme activities to ensure their stability; while other pieces were involved in antimicrobial tests against tomato black mold incidence as follows.

Antimicrobial activity of enzyme-saturated polyester films on tomato fruit and black mold incidence

Intact tomato fruits $(55 \pm 10 \mathrm{~g})$ were selected, cleaned and washed by tap water then by distilled water. The tomato fruits were distributed separately in petri dishes. The experiment was designated as follow where each treatment was performed in triplicate:

\section{General control}

The fruits were stored without any treatments.

\section{Infected control}

A small hole $(1 \times 1 \mathrm{~cm})$ was done in each fruit by sterilized scalpel, then inoculated by fungal disc (8mm) of A. alternata.

\section{Polyester films}

The fruits were infected as previous then each fruit covered completely by the polyester film amended by glucose oxidase, chitinase and cellulase enzymes separately. (The steps of infection and covering the tomato fruits by polyester films were shown in Photo 1)

\section{Control of polyester films}

This was designated to test the effect of the polyester films amended by crude enzymes extracts on the tomato fruits themselves. Three straight wounds (about 10mm) were done on each fruit by sterilized scalpel then covered by polyester films amended with distilled water and crude enzyme extracts separately.

All the fruits were stored up to 15 days in dark at room temperatures (Max: $26^{\circ} \mathrm{C}$, Min: $14^{\circ} \mathrm{C}$ ). The disease incidence was calculated as mentioned in Aborisade \& Olusola (2016) after 4, 7, 10 and 15 days as follow:

\section{Disease incidence $=\mathrm{N} / 3 \times 100$}

where; $\mathrm{N}=$ number of fruits with spoiled lesions surrounded the inoculated fungal disc and 3 is the total number of inoculated fruits.

Also, the activity of the prepared films in reduction of fungal growth of A. alternata and spoiled lesions area on tomato fruits was calculated using the percentage growth inhibition (I \%) according to the infected control.

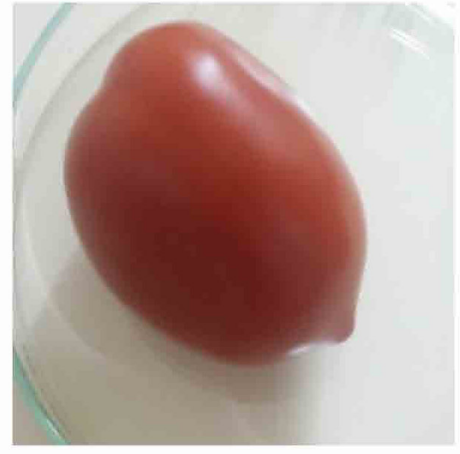

1. The intact tomato fruit.

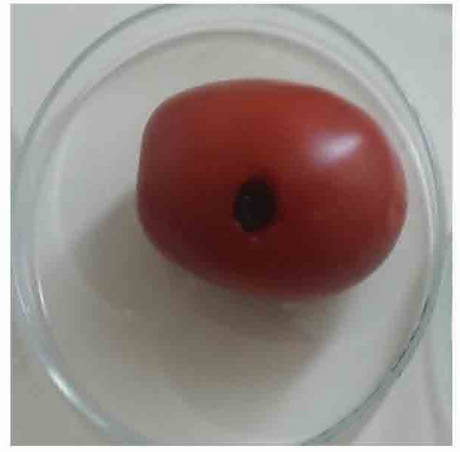

2. Making a hole and infect it by disc of $A$. alternata disc.

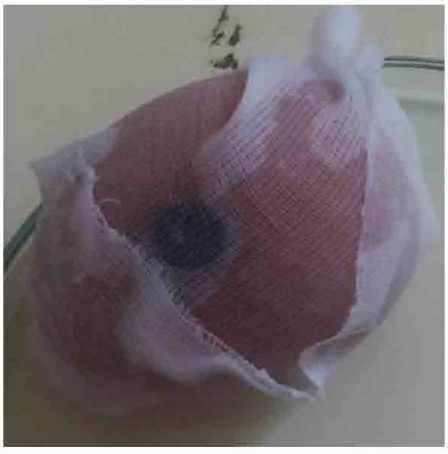

3. Covering the infected fruit by the polyester film.

Photo.1. Steps of infection and covering the tomato fruit by polyester films. 
Statistical analysis

Statistical analysis of the present study was conducted, using the mean, standard deviation and analysis of variance "ANOVA" using Microsoft Excel 2016 programme and the online free source; Free Statistics Calculators version 4.0.

\section{$\underline{\text { Results }}$}

Antifungal activity of $T$. harzianum against $A$. alternata in vitro

In vitro investigations of the dual culture of $T$. harzianum against $A$. alternata revealed that, the growth of $A$. alternata was inhibited ( $\mathrm{I}=66.5 \%$ ) as a result of the growth of T.harzianum. Photo 2 shows the over growth of $T$. harzianum mycelia on the mycelial growth of A. alternata. Moreover, Photo 3 illustrated the hyphal interaction mechanisms between $T$. harzianum and $A$. alternata. The hyphae of T. harzianum penetrated inside the hyphae of $A$. alternata leading to their lysis (Photo 3A), also, the conidial shape of $A$. alternata was malformed (Photo $3 \mathrm{~B}$ ). This lysis of hyphal cells of $A$. alternata might be due to the secretion of lytic enzymes of $T$. harzianum. Accordingly, the presence and activity of some offensive lytic enzymes (cellulase, chitinase and glucose oxidase) were assayed for the tested antagonist, T. harzianum.

Stability test for all enzymes in the collected filtrates and polyester films

The antagonistic fungus, $T$. harzianum possesses an observable enzymatic activity as a tool for attacking other pathogenic fungi, that was evaluated in the present study. Cellulase activity was recorded in Table 1 as it started with $14.14 \mathrm{u} \mathrm{ml}^{-1}$ in the crude culture filtrate, which was significantly decreased by time to reach $3.79 \mathrm{u} \mathrm{ml}^{-1}$ after stored for $24 \mathrm{~h}$. This indicating the loss of enzyme activity from $100 \%$ to $27 \%$ during storage at room temperature. Also, the activity of chitinase enzyme of T. harzianum was recorded in Table 2 where it started with $4.72 \mathrm{u}$ $\mathrm{ml}^{-1}$ in the crude culture filtrate, and significantly decreased by time to reach $1.65 \mathrm{u} \mathrm{ml}^{-1}$ after 24 $\mathrm{h}$. This means that, the enzyme activity was decreased from $100 \%$ to $35 \%$ during storage at room temperature. Similar observations were considered for glucose oxidaseas an important tool in fungal cell metabolism and ligninolytic systems of T. harzianum. The activity of glucose oxidase was recorded in Table 3 as it started with $8.35 \mathrm{u} \mathrm{ml}^{-1}$ in the crude culture filtrate, which was significantly decreased by time to reach $2.13 \mathrm{u}$ $\mathrm{ml}^{-1}$ after $24 \mathrm{~h}$. This revealed the loss of enzyme activity from $100 \%$ to $35 \%$ during storage period at room temperature. A promising observation was recorded for all the tested enzymes where their stability was increased with immobilization of each enzyme separately within polyester cloth pieces at room temperature. The enzyme activity was maintained up to $93 \%, 91 \%$ and $90 \%$ for cellulase, chitinase and glucose oxidase after stored to $24 \mathrm{~h}$, respectively.

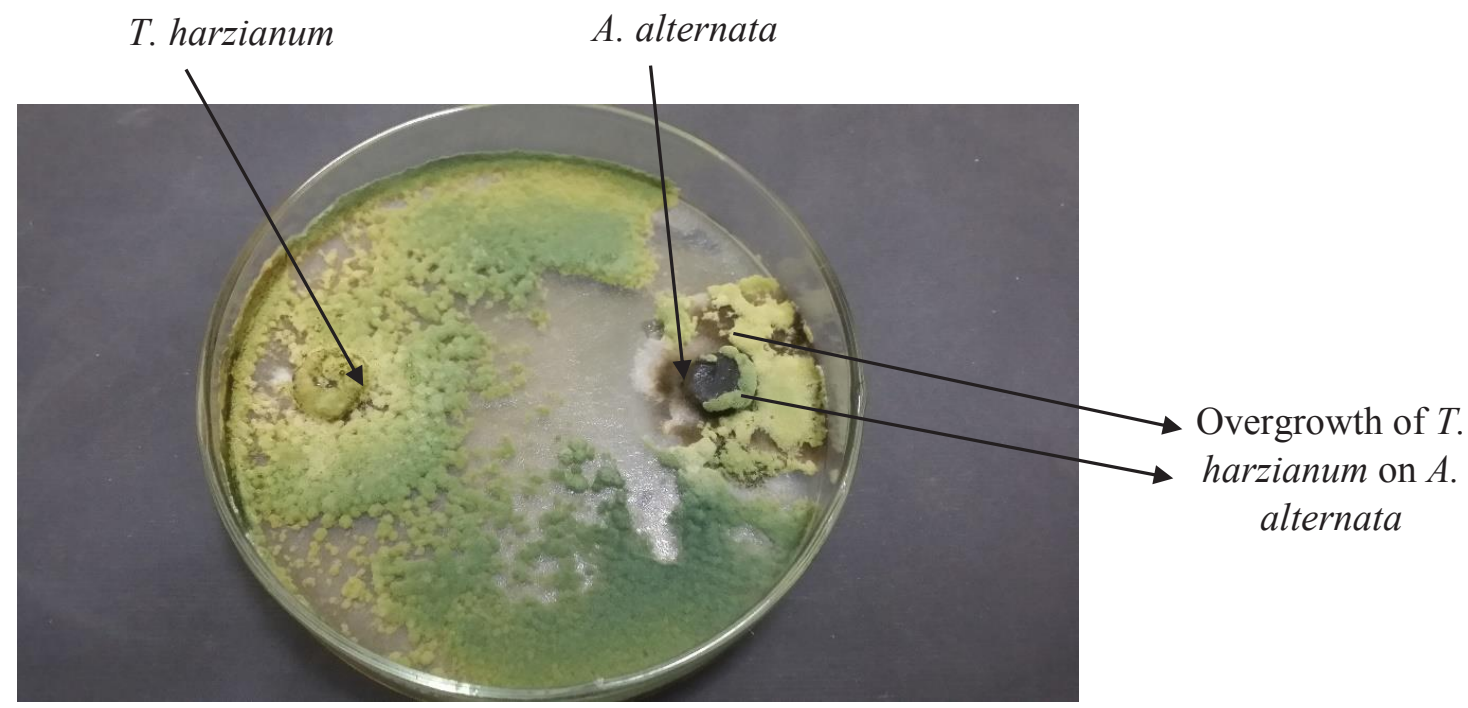

Photo 2. Dual cultute between T. harzianum and A. alternata. 


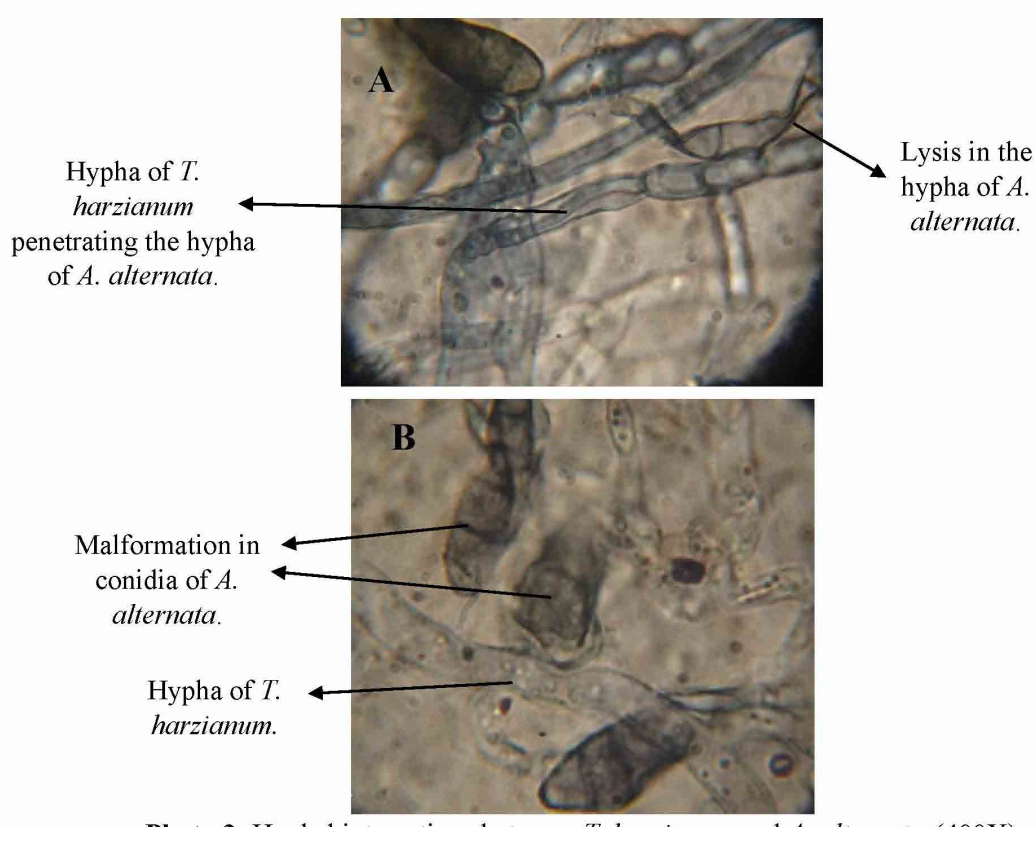

Photo 3. Hyphal interactions between T. harzianum and A. alternata.

TABLE 1. Extracellular cellulase activity of T. harzianum and its stability in crude filtrates and saturated polyester films.

\begin{tabular}{|c|c|c|c|c|c|c|c|}
\hline \multirow{3}{*}{ Treatment } & \multirow{3}{*}{ Value } & \multirow{2}{*}{\multicolumn{4}{|c|}{$\begin{array}{l}\text { Cellulase activity }\left(\mathrm{u} \mathrm{ml}{ }^{-1} \pm \mathrm{SD}\right) \\
\text { after regular storage intervals }(\mathrm{h})\end{array}$}} & \multirow{2}{*}{\multicolumn{2}{|c|}{ ANOVA }} \\
\hline & & & & & & & \\
\hline & & $\mathbf{0}$ & 6 & 12 & 24 & F-value & $\mathbf{P}$ \\
\hline \multirow{2}{*}{$\begin{array}{l}\text { Crude cell-free } \\
\text { filtrate }\end{array}$} & $\begin{array}{l}\text { Enzyme } \\
\text { activity }\end{array}$ & $14.14 \pm 0.31$ & $11.88 \pm 0.27$ & $8.31 \pm 0.22$ & $3.79 \pm 0.11$ & 1066.851 & $0.000^{*}$ \\
\hline & $\begin{array}{l}\% \text { Remaining } \\
\text { activity }\end{array}$ & 100 & 84 & 59 & 27 & & \\
\hline \multirow{2}{*}{$\begin{array}{l}\text { Immobilized } \\
\text { enzyme- } \\
\text { saturated } \\
\text { polyester films }\end{array}$} & $\begin{array}{l}\text { Enzyme } \\
\text { activity }\end{array}$ & $3.75 \pm 0.12$ & $3.63 \pm 0.13$ & $3.60 \pm 0.12$ & $3.48 \pm 0.09$ & 2.743 & 0.113 \\
\hline & $\begin{array}{c}\% \text { Remaining } \\
\text { activity }\end{array}$ & 100 & 97 & 96 & 93 & & \\
\hline
\end{tabular}

TABLE 2. Extracellular chitinase activity of T. harzianum and its stability in crude filtrates and saturated polyester films.

\begin{tabular}{|c|c|c|c|c|c|c|c|}
\hline \multirow{3}{*}{ Treatment } & \multirow{3}{*}{ Value } & \multirow{2}{*}{\multicolumn{4}{|c|}{$\begin{array}{l}\text { Chitinase activity }\left(\mathrm{u} \mathrm{ml}^{-1} \pm \mathrm{SD}\right) \\
\text { after regular storage intervals }(\mathrm{h})\end{array}$}} & \multirow{2}{*}{\multicolumn{2}{|c|}{ ANOVA }} \\
\hline & & & & & & & \\
\hline & & 0.0 & 6 & 12 & 24 & F-value & $\mathbf{P}$ \\
\hline \multirow[b]{2}{*}{ Crude cell-free filtrate } & Enzyme activity & $4.72 \pm 0.26$ & $3.55 \pm 0.23$ & $2.28 \pm 0.18$ & $1.65 \pm 0.12$ & 133.695 & $0.000^{*}$ \\
\hline & $\begin{array}{l}\% \text { Remaining } \\
\text { activity }\end{array}$ & 100 & 75 & 48 & 35 & & \\
\hline \multirow{2}{*}{$\begin{array}{l}\text { Immobilized enzyme- } \\
\text { saturated polyester } \\
\text { films }\end{array}$} & Enzyme activity & $1.62 \pm 0.09$ & $1.58 \pm 0.09$ & $1.53 \pm 0.08$ & $1.47 \pm 0.08$ & 1.738 & 0.236 \\
\hline & $\begin{array}{l}\% \text { Remaining } \\
\text { activity }\end{array}$ & 100 & 98 & 94 & 91 & & \\
\hline
\end{tabular}

SD: Standard deviation \& P: probability

*: Significant at $\mathrm{P} \leq 0.05$ 
TABLE 3. Extracellular glucose oxidase activity of $T$. harzianum and its stability in crude filtrates and saturated polyester films.

\begin{tabular}{|c|c|c|c|c|c|c|c|}
\hline \multirow{2}{*}{ Treatment } & \multirow[t]{2}{*}{ Value } & \multicolumn{4}{|c|}{$\begin{array}{c}\text { Glucose oxidase activity }\left(\mathrm{u} \mathrm{ml}^{-1} \pm \mathrm{SD}\right) \text { after regular } \\
\text { storage intervals (h) }\end{array}$} & \multicolumn{2}{|c|}{ ANOVA } \\
\hline & & 0.0 & 6 & 12 & 24 & F-value & $\mathbf{P}$ \\
\hline \multirow{2}{*}{$\begin{array}{l}\text { Crude cell-free } \\
\text { filtrate }\end{array}$} & $\begin{array}{l}\text { Enzyme } \\
\text { activity }\end{array}$ & $8.53 \pm 0.24$ & $6.64 \pm 0.22$ & $3.24 \pm 0.16$ & $2.13 \pm 0.12$ & 723.619 & $0.000^{*}$ \\
\hline & $\begin{array}{l}\% \text { Remaining } \\
\text { activity }\end{array}$ & 100 & 78 & 38 & 25 & & \\
\hline \multirow{2}{*}{$\begin{array}{l}\text { Immobilized } \\
\text { enzyme-saturated } \\
\text { polyester films }\end{array}$} & $\begin{array}{l}\text { Enzyme } \\
\text { activity }\end{array}$ & $2.13 \pm 0.17$ & $2.04 \pm 0.12$ & $1.99 \pm 0.11$ & $1.91 \pm 0.11$ & 1.510 & 0.285 \\
\hline & $\begin{array}{l}\text { \% Remaining } \\
\text { activity }\end{array}$ & 100 & 96 & 93 & 90 & & \\
\hline
\end{tabular}

SD: Standard deviation \& P: probability

*: Highly significant at $\mathrm{P} \leq 0.05$

Antimicrobial activity of enzyme-saturated polyester films on tomato fruit and black mold incidence

All the general control fruits were intact all over the experiment time but some of them began to normally spoiled and attacked by normal postharvest infections after 10 and 15 days where the postharvest infections incidence was 33.33 and $66.66 \%$, respectively (Photo 5 A \& B). The results in Table 4 and Photos $4 \&$ 5 illustrated the activity of the polyester films immobilized with crude enzymes extract of (glucose oxidase, chitinase and cellulase) of $T$. harzianum on the growth of $A$. alternata and the development of black rot disease on tomato fruit after 4, 7, 10 and 15 days. Films with crude extract of glucose oxidase enzyme revealed negative results in inhibition of fungal growth and disease incidence related to the infected control. The disease incidence was $100 \%$ and the inhibition percentage of $A$. alternata was -6.16 after 4 days. This means that the presence of glucose oxidase film increases the fungal growth and spoilage of tomato fruit tissues more than the infected control.

The results also revealed that, the polyester film immobilized with crude extract of cellulase enzyme recorded the best results in protecting the fruit from black mold incidence. The growth of $A$. alternata was limited only inside the holes made on tomato fruit without spoiling of the surrounded tissues after stored for 4 and 7 days (Photo 4 A \& B). This result indicated that the immobilized cellulase enzyme affected only the pathogen and in the same time did not degrade the tomato tissues. Therefore, the inhibition percentage was 45.72 and $46.06 \%$ after 4 and 7 days while, the disease incidence was $0 \%$ after the two periods. The above results were illustrated according to the fact revealed that, cellulose and hemicellulose of normal tomatoes decreased during ripening (Huber, 1983 and Lunn et al., 2013). Consequently, by increasing storage period, the disease incidence began to appear where it became 33.3 and $100 \%$ after 10 and 15 days, respectively (Photo 5: A \& B). In the meantime, film of chitinase enzyme gave small values of inhibition percentage (2.22 and $1.34 \%$ ) after 4 and 7 days, respectively with disease incidence equal $66.66 \%$. Then the disease incidence became $100 \%$ after 10 days with negative inhibition percentage (-30\%) where the fungal growth and spoiled area on tomato fruit was increased more than the infected control.

The effect of polyester films immobilized by enzymes of $T$. harzianum on wounded tomato fruit was shown in Photo.6. Control films were immobilized by distilled water. The obtained results indicated that, the used films did not affect the intact part of each tomato fruit while the wounded parts were more suitable to spoiling and infections by increasing storage period. Cellulase enzyme films protected the wounded fruit from infections for long period than the other films where the fruit remain intact, but somewhat shrinkage, to 10 days storage. 
TABLE 4. Effect of enzyme polyester films on the development of black rot on tomato fruit inoculated with $A$. alternata.

\begin{tabular}{lcccccccc}
\hline \multirow{2}{*}{\begin{tabular}{l} 
Enzyme-polyester \\
\cline { 2 - 8 }
\end{tabular}} & \multicolumn{3}{c}{ I (\%) after period (days) } & \multicolumn{3}{c}{ Disease incidence (\%) after period (days) } \\
\cline { 2 - 8 } & $\mathbf{4}$ & $\mathbf{7}$ & $\mathbf{1 0}$ & $\mathbf{1 5}$ & $\mathbf{4}$ & $\mathbf{7}$ & $\mathbf{1 0}$ & $\mathbf{1 5}$ \\
\hline Glucose oxidase & -6.16 & -3.6 & -9.7 & -40.42 & 100 & 100 & 100 & 100 \\
Chitinase & 2.22 & 1.34 & -30 & -4.3 & 66.66 & 66.66 & 100 & 100 \\
Cellulase & 45.72 & 46.06 & 56.96 & 18.19 & 0 & 0 & 33.33 & 100 \\
\hline
\end{tabular}
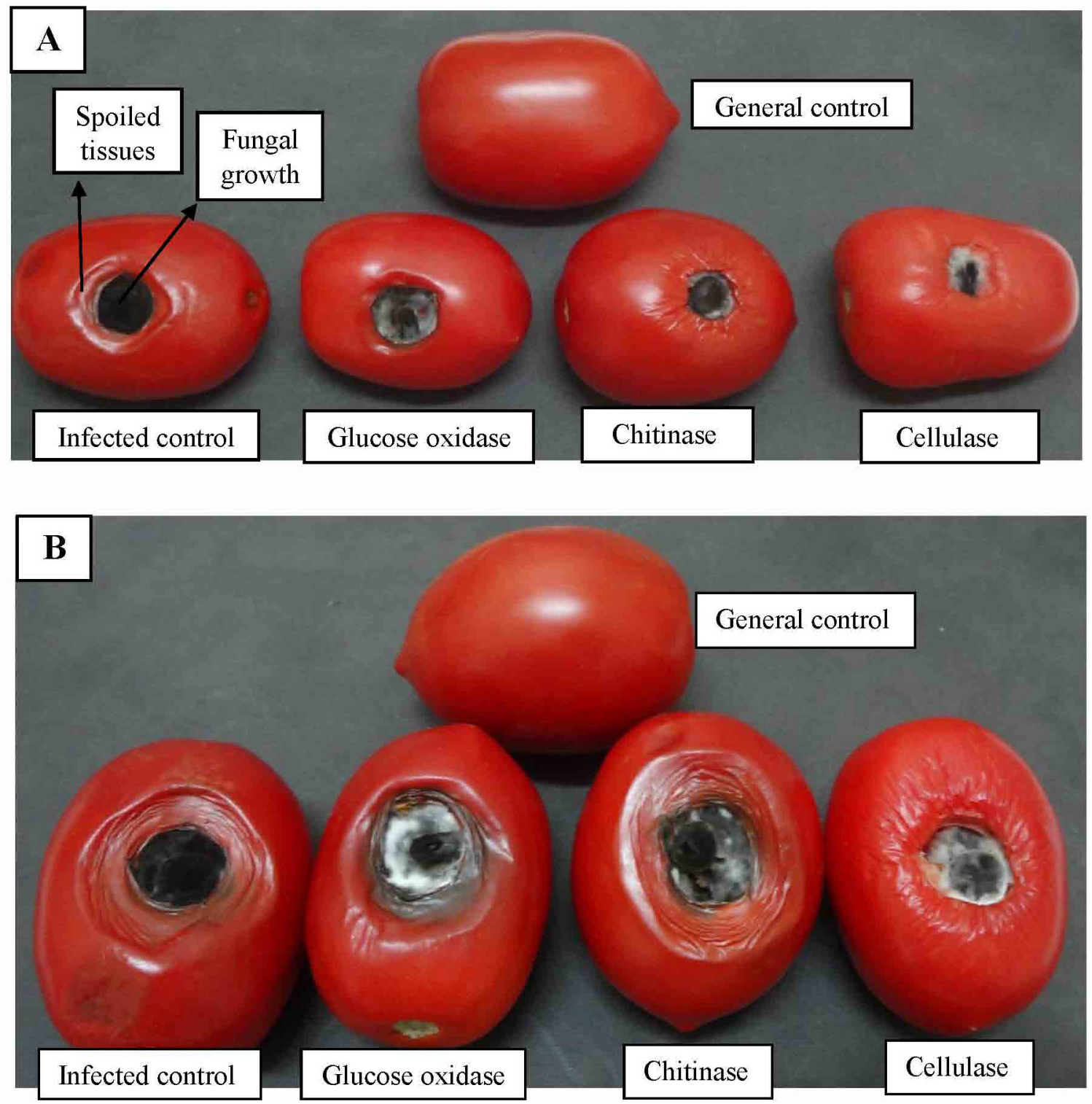

Photo 4.Effect of polyester films of enzymes of T. harzianum on the growth of $A$. alternata and black rot incidence on tomato fruit after 4 days (A) and 7 days (B). 

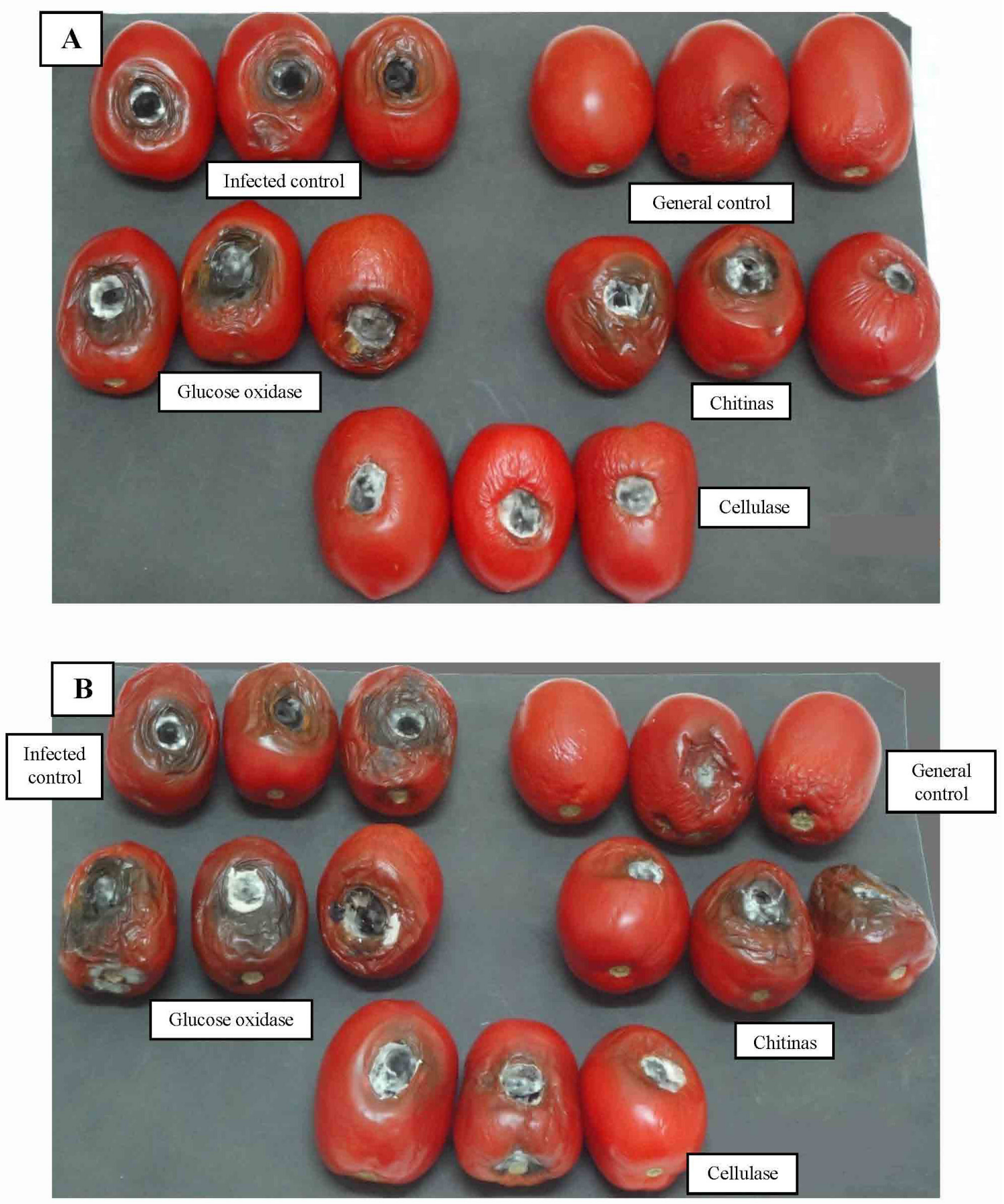

Photo 5. Effect of polyester films of enzymes of T. harzianum on the growth of $A$. alternata and black rot incidence on tomato fruit after 10 days (A) and 15 days (B). 


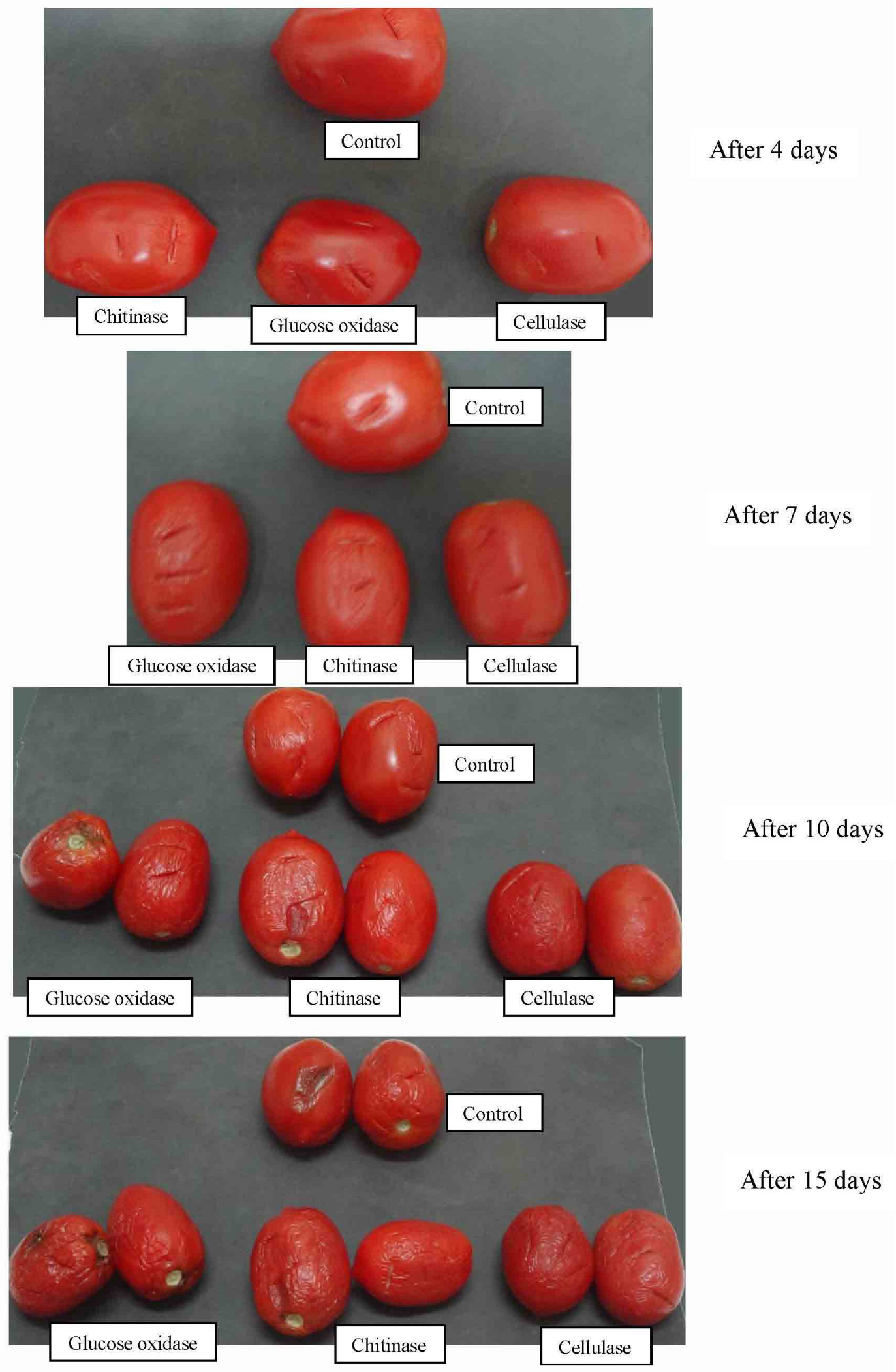

Photo 6. Effect of polyester films of enzymes of T. harzianum on wounded tomato fruit. 


\section{Discussion}

The present findings represent that $T$. harzianum recorded an antifungal activity against A. alternata in dual culture using mycoparasitism and antibiosis mechanisms. This is in agreement with a previous study of the second author (ElDebaiky, 2017) who examined the activity of T. harzianum on the growth of other isolate of A. alternata in paired plates and found that the inhibition percentage was $61.58 \%$. In addition, she reported that $T$. harzianum attacked the hyphae of $A$. alternata by coiling around them leading to their lysis.

The immobilized enzymes of $T$. harzianum on polyester films in this study show promising stability than in free-cell filtrate. These findings agree with other studies which revealed that, immobilization of the enzyme to a matrix prevents excessive loss of enzyme activity after immobilization, increases enzyme stability in microenvironment of matrix and protects enzyme from microbial contamination (Cabral \& Kennedy, 1993). Also, the immobilization of amylases on different activated fabrics increases the enzymatic stability than the free enzyme (Rani, 2012). On the other hand, in the present work the enzymes immobilized films were tested against black mold incidence of tomato fruit and the results revealed that glucose oxidase enzyme recorded lowest results followed by chitinase then cellulase which was the best. These findings may be due to the formation of $\mathrm{H}_{2} \mathrm{O}_{2}$ in the oxidation process of glucose using glucose oxidase. Then, the formed $\mathrm{H}_{2} \mathrm{O}_{2}$ was used with the ligninolytic enzyme of the pathogen in degradation of lignin found in tomato fruit tissues (Zhao \& Janse, 1996 and Eichlerová et al., 2006).

Also, the results of chitinase and cellulase showed an unexpected behavior of the enzymatic activity of T. harzianum against the hyphae of $A$. alternata. Where the cell walls of deuteromycetes did not contain cellulose but, the pathogen; $A$. alternata was markedly inhibited by cellulase enzyme of $T$. harzianum immobilized on the polyester cloth pieces after 4 and 7 days. These interesting findings may be illustrated according to other literatures. The cell walls of Alternaria sp. consists mainly from glucuronic acid which is characteristic to plant cell wall hemicelluloses (Gancedo et al., 1966). The glucuronic acid is closely related to cellulose where it contains $\beta$
(1-4) linkage (Tavernier et al., 2008) also, polyglucuronic acid can be produced by selective oxidation of cellulose using nitrogen oxides (Yackel \& Kenyon, 1942 and Maurer \& Reiff, 1943). While, the production and antifungal activity of chitinase enzyme of $T$. harzianum may be suppressed or activated by many compounds produced during the relationship among the pathogen, the antagonist and the host plant (Ulhoa \& Peberdy, 1991). Accordingly, the chitinolytic antifungal activity of $T$. harzianum against $A$. alternata was found to be unexpectedly moderate than the cellulolytic activity.

\section{Conclusion}

The antagonist, T. harzianum was tested for its antifungal activity against $A$. alternata, the causal agent of postharvest black mold of tomato fruit. It inhibited the mycelial growth of $A$. alternata by attacking its mycelia using the mycoparasitism, antibiosis and lytic enzymes mechanisms. Polyester film immobilization of $T$. harzianum enzymes (cellulase, chitinase and glucose oxidase) raised their stability and persistence at room temperature. These enzymes of T. harzianum immobilized on polyester cloth films were tested for their activity in preserving tomato fruit against spoilage by black mold. Cellulase followed by chitinase showed observable antifungal activity against $A$. alternata and protecting the tomato fruit from black mold incidence for prolonged time whenever they were contact without wounds. This study is considered a base for further studies in food protecting technology filed using the immobilized enzymes on polyester cloth films in packing fruit and other foods in storage.

\section{References}

Aborisade, A. and Olusola, F. (2016) Original Research Reports. Nigerian Journal of Mycology, 8, 1-7.

Asan, A. and Ekmekci, S. (2002) Contribution to the colonial and morphological characteristics of some Aspergillus species isolated from soil. J. Fac. Sci. Ege. Univ. 25, 121-139.

Budi, S., Van Tuinen, D., Arnould, C., DumasGaudot, E., Gianinazzi-Pearson, V. and Gianinazzi, S. (2000) Hydrolytic enzyme activity of Paenibacillus sp. strain B2 and effects of the antagonistic bacterium on cell integrity of two 
soil-borne pathogenic fungi. Applied Soil Ecology, 15, 191-199.

Cabral, J. and Kennedy, J. (1993 "Immobilization Techniques For Altering Thermal Stability Of Enzymes", Springer Verlag: Berlin.

Causse, M., Buret, M., Robini, K. and Verschave, P. (2003) Inheritance of nutritional and sensory quality traits in fresh market tomato and relation to consumer preferences. Journal of Food Science, 68, 2342-2350.

Cha, D.S. and Chinnan, M.S. (2004) Biopolymer-based antimicrobial packaging: A review. Critical Reviews In Food Science And Nutrition, 44, 223-237.

Eichlerová, I., Homolka, L. and Nerud, F. (2006) Ability of industrial dyes decolorization and ligninolytic enzymes production by different Pleurotus species with special attention on Pleurotus calyptratus, strain Ccbas 461. Process Biochemistry, 41, 941-946.

El-Debaiky, S.A. (2017) Antagonistic studies and hyphal interactions of the new antagonist Aspergillus piperis against some phytopathogenic fungi in vitro in comparison with Trichoderma harzianum. Microbial Pathogenesis, 113, 135-143.

Gancedo, J., Gancedo, C. and Asensio, C. (1966) Uronic acids in fungal cell walls. Biochemische Zeitschrift, 346(4), 328.

Henrissat, B., Driguez, H., Viet, C. and Schulein, M. (1985) Synergism of cellulases from Trichoderma reesei in the degradation of cellulose. Nature Biotechnology, 3, 722-726.

Huber, D.J. (1983) The role of cell wall hydrolases in fuit softening. Horticultural Reviews, 5, 169-219.

Jamdar, Z., Mohammadi, A. and Mohammadi, S. (2013) Study of antagonistic effects of Trichoderma species on growth of Verticillium dahliae, the causal agent of Verticillium wilt of Pistachio under laboratory condition. Journal of Nuts, 4, 53-56.

Jayasinghe, C. and Wijesundera, R. (1995) In vitro evaluation of fungicides against clove isolate of Cylindrocladium quinqueseptatum In Sri Lanka. International Journal of Pest Management, 41, 219-223.
Joshi, S., Kozlowski, M., Selvaraj, G., Iyer, V. and Davies, R. (1988) Cloning of the genes of the chitin utilization regulon of Serratia liquefaciens. Journal of Bacteriology, 170, 2984-2988.

Kelley, R. and Reddy, C.A. (1986) Purification and characterization of glucose oxidase from ligninolytic cultures of Phanerochaete chrysosporium. Journal of Bacteriology, 166, 269-274.

Kim, C.S., Kamiya, S., Sato, T., Utsumi, S. and Kito, M. (1990) Improvement of nutritional value and functional properties of soybean glycinin by protein engineering. Protein Engineering, Design and Selection, 3, 725-731.

Lingk, W. (1991 "Health Risk Evaluation Of Pesticide Contaminations In Drinking Water. Gesunde Pflanzen" (Germany, Fr).

Lunn, D., Phan, T.D., Tucker, G.A. and Lycett, G.W. (2013) Cell wall composition of tomato fruit changes during development and inhibition of vesicle trafficking is associated with reduced pectin levels and reduced softening. Plant Physiology and Biochemistry, 66, 91-97.

Mandels, M., Andreotti, R. and Roche, C. (1976) Measurement of saccharifying cellulase. biotechnol. Bioeng. Symp.;(United States), Army Natick Development Center, Ma.

Maurer, K. and Reiff, G. (1943) Die oxydation der cellulose mit stickstoffdioxyd 2. mitteilung Über oxydationen Mit No2. Advanced Synthesis \& Catalysis, 1, 27-34.

Moubasher, A. (1993) "Soil Fungi in Qatar and Other Arab Countries", The Centre For Scientific and Applied Research, University of Qatar.

Moussa, S., Sharma, A., Baiomy, F. and El-Adl, F. E. (2013) The status of tomato leafminer, Tuta absoluta (Meyrick) (Lepidoptera: Gelechiidae) in Egypt and potential effective pesticides. Academic Journal of Entomology, 6, 110-115.

Papavizas, G. (1985) Trichoderma and Gliocladium: Biology, ecology, and potential for biocontrol. Annual Review of Phytopathology, 23, 23-54.

Rani, K. (2012) Immobilization of Vigna radiate, Vigna mungo, Cicer arietinum (White) and Cicer 
arietinum (Black) amylases onto variety of activated fabrics. Int. J. Life Sci Pharma Res. 1, 124-133.

Reese, E. T. and Mandels, M. (1959) B-D-1, 3 glucanases in fungi. Canadian Journal of Microbiology, 5, 173-185.

Sajad, A. and Jamaluddin Abid, H. (2017) Fungi associated with the spoilage of post harvest tomato fruits and their frequency of occurrences in different markets of Jabalpur, Madhya-Pradesh, India. Int. J. Cur. Res. Rev. 9, 12-16.

Samuel, O. and Orji, M. (2015) Fungi associated with the spoilage of postharvest tomato fruits sold in major markets in Awka, Nigeria. Universal Journal Of Microbiology Research, 3, 11-16.

Spotts, R. and Cervantes, L. (1986) Populations, pathogenicity, and benomyl resistance of Botrytis spp., Penicillium spp., and Mucor piriformis In Packinghouses. "Plant Disease" (USA).

Talvas, J., Caris-Veyrat, C., Guy, L., Rambeau, M., Lyan, B., Minet-Quinard, R., Lobaccaro, J.M. A., Vasson, M.P., George, S. and Mazur, A. (2010)Differential effects of lycopene consumed in tomato paste and lycopene in the form of a purified extract on target genes of cancer prostatic cells. The American Journal of Clinical Nutrition, 91, 1716-1724.

Tanaka, K., Saji, H. and Kondo, N. (1988)
Immunological properties of Spinach glutathione reductase and inductive biosynthesis of the enzyme with ozone. Plant and Cell Physiology, 29, 637-642.

Tavernier, M., Delattre, C., Petit, E. and Michaud, P. (2008) B-(1,4)-Polyglucuronic acids, an overview. Open Biotechnol. J. 2, 73-86.

Troncoso-Rojas, R. and Tiznado-Hernández, M.E. (2014) Alternaria alternata (Black rot, Black spot). Postharvest Decay Control Strategies, 147-188.

Ulhoa, C.J. and Peberdy, J.F. (1991) Regulation of chitinase synthesis in Trichoderma harzianum. Microbiology, 137, 2163-2169.

Vincent, J. (1947) Distortion of fungal hyphae in the presence of certain inhibitors. Nature, 159, 850.

Yackel, E.C. and Kenyon, W.O. (1942) The oxidation of cellulose by nitrogen dioxide. Journal of the American Chemical Society, 64, 121-127.

Zhao, J. and Janse, B.J. (1996) Comparison of $\mathrm{H}_{2} \mathrm{O}_{2}-$ producing enzymes in selected white rot fungi. Fems Microbiology Letters, 139, 215-221.

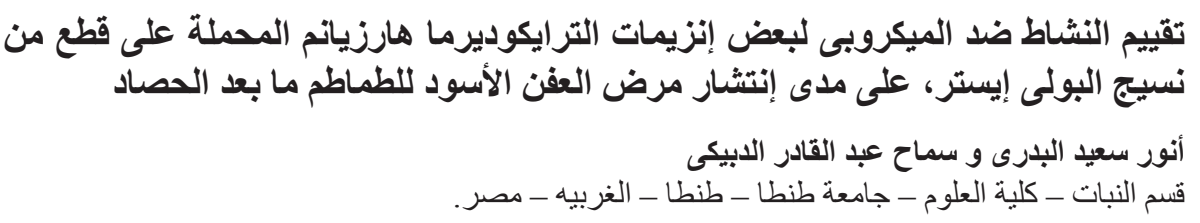

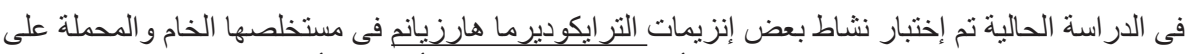

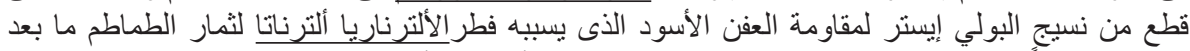

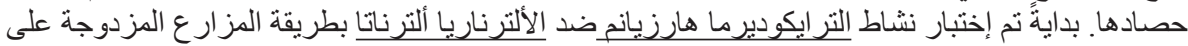

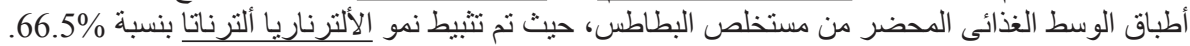

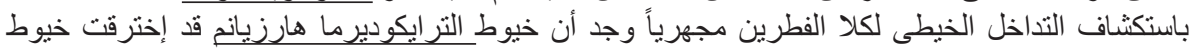

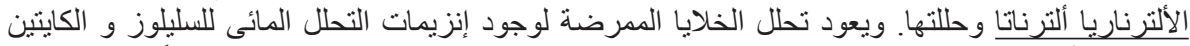

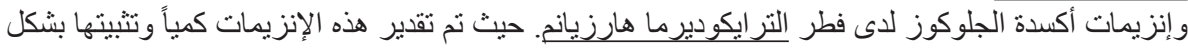

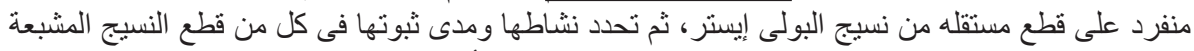

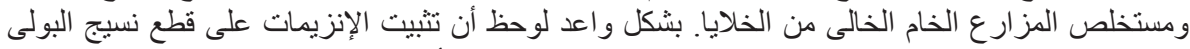

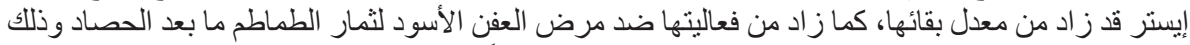

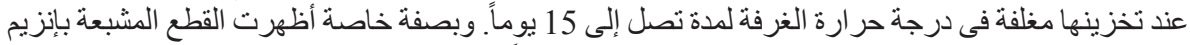

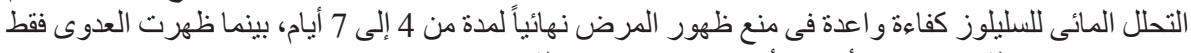
فى 33.3\% من الثمار بعد 10 أيام، و أصييت 100\% من الثعة الثمار بعد 15 يوم. 